DoRota MURZYN

Pedagogical University of Krakow, Poland

\title{
Social entrepreneurship and selected elements of the entrepreneurship ecosystem
}

\begin{abstract}
The article aims to analyse the development of social entrepreneurship in the entrepreneurial ecosystem's context based on the example of three countries: Poland, Italy and North Macedonia. The theoretical framework for the analysis and interpretation of the results is determined by new institutional economics and entrepreneurship theories. In turn, the empirical part is based on the analysis of selected indicators on the development of social entrepreneurship; a diagnostic survey has also been carried out among stakeholders (representatives of entities related to social entrepreneurship), and young people in Poland, Italy and North Macedonia. The analysis allows for the of the leading research hypothesis which assumes that one of the most essential and basic elements of the social entrepreneurship ecosystem is knowledge, and its low level within society is a barrier to its development. To make the most of its potential, and increase employment in social enterprises, it is essential to integrate social entrepreneurship with mainstream entrepreneurship and business education.
\end{abstract}

Keywords: entrepreneurial ecosystem; entrepreneurship; social enterprises; social entrepreneurship

Received: 22 October 2020

Accepted: 12 February 2021

\section{Suggested citation:}

Murzyn, D. (2021). Social entrepreneurship and selected elements of the entrepreneurship ecosystem. Przedsiębiorczość - Edukacja [Entrepreneurship - Education], 17(1), 165-176. https://doi. org/10.24917/20833296.171.13

\section{Introduction}

Social entrepreneurship is a practice that has been dynamically developing in recent years and has become an area of growing interest in academic circles. This situation is influenced by many factors, including actions taken at a European level. When the European Commission launched the Social Business Initiative in 2011, one of its priorities was to increase the social enterprise business model's visibility and recognition. Following that 
initiative, member states have adopted specific legislation in this area, and some have developed formal strategies or policies to support the development of social enterprises. The level of maturity in this area and the understanding and acceptance of the concept of a social enterprise by policymakers, practitioners, and researchers vary considerably between EU member states and beyond.

The article aims to analyse the development of social entrepreneurship in the entrepreneurial ecosystem's context based on the example of three countries: Poland, Italy and North Macedonia. These are countries with different histories, different levels of socio-economic development and different levels in social entrepreneurship development. The preliminary analysis has allowed the central research hypothesis to be formulated. It assumes that one of the most essential and basic elements of the social entrepreneurship ecosystem is knowledge, but its low level within society is a barrier to its development.

The theoretical framework for the analysis and interpretation of the results is defined by new institutional economics and entrepreneurship theories. In turn, the empirical part is based on an analysis of selected indicators of social entrepreneurship development and a diagnostic survey carried out among stakeholders (representatives of entities related to social entrepreneurship) and the young in Poland, Italy and North Macedonia ${ }^{1}$.

\section{Social entrepreneurship - interpretative contexts}

Social entrepreneurship has become an increasingly important dynamic over recent decades in most European countries. However, social enterprises are still viewed very differently by national legislations and policies, academics and the social entrepreneurs themselves, not to mention society as a whole.

Social entrepreneurship, at its most basic level, means conducting business for social purposes. Thus, the concept of 'social enterprise' combines two attributes: 'entrepreneurship' (activities that involve economic risk and economic verification of their effects) and 'society' (its operation is aimed at achieving social goals) (Hausner, Laurisz, 2008: 9). It is also how social enterprises are defined by the European Research Network EMES, emphasising that initiatives which fit in with social entrepreneurship should be characterised by meeting both economic and social criteria (Defourny, Nyssens, 2008) (Figure 1).

Figure 1. Definition of a social enterprise (EMES)
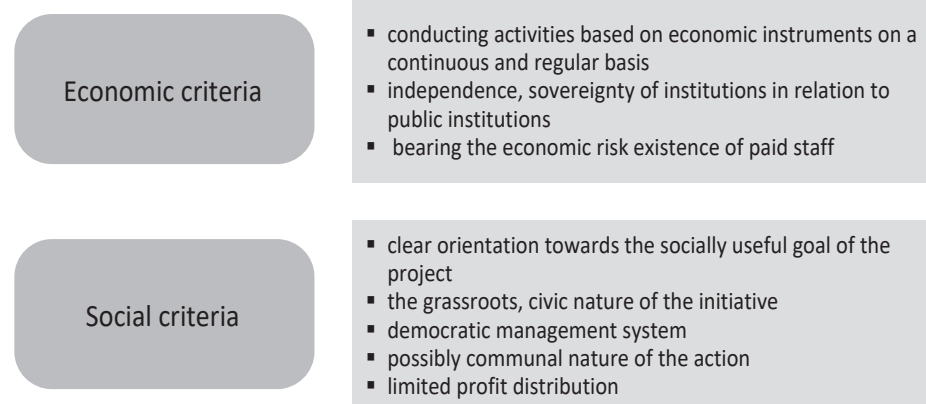

Source: author, based on Defourny, Nyssens (2008: 37)

${ }^{1}$ These studies were carried out as part of the project "INN@SE - Innovative social entrepreneurship with youth engagement” co-financed by the European Union (2019-3-PL01-KA205-077684). 
Based on EMES's research, further attempts were made to operationalise the definition of 'social enterprise'. In line with a concept based on the Social Business Initiative (SBI) promoted by the European Commission, a social enterprise relates to three dimensions. Social enterprises carry out commercial activities (entrepreneurial - the economic dimension) to achieve a social or common good (the social dimension) and have an organisation or ownership system that reflects their mission (inclusive management - the ownership dimension) (European Commission, 2020a: 28).

A social enterprise is a company that allows social problems to be solved with the help of business tools. While entrepreneurship aims to start and run a new enterprise to create economic wealth, social entrepreneurship focuses on setting up a business venture to create social capital and make a profit that is going to be used primarily to achieve social goals.

In organisational terms, social entrepreneurship covers a diverse group of entities and initiatives. Social enterprises can operate in various forms such as social cooperatives, non-profit organisations (e.g. associations, voluntary organisations, charities or foundations). For example, in Poland, the National Program for the Development of the Social Economy (2019) included entities operating in the field of public benefit (non-governmental organisations conducting economic activity), economic organisations (cooperatives, non-profit companies), reintegration entities (e.g. professional activity establishments, social integration centres), social enterprises, and also informal initiatives (e.g. cooperatives, student cooperatives). Social entrepreneurs are often associated with various sectors and non-profit organisations, but this does not eliminate the need to profit as social enterprises need capital to run their businesses and bring positive change to society.

Social entrepreneurs represent an innovative approach to solving critical and neglected social problems, mobilising ideas, abilities and the social resources necessary for lasting social change (Bornstein, 2004). As Schumpeter wrote, they are reformers and revolutionaries but have a social mission (Dees, 2001). Sometimes social entrepreneurship is defined as the economic activity of creating new models for the delivery of products and services to meet the basic human needs of the most impoverished social strata that remain unmet by current economic or social institutions (Seelos, Mair, 2005).

Initially, most social enterprises aim to create jobs for specific groups such as the disabled or the long-term unemployed. However, over the last thirty years, an understanding of social entrepreneurship has developed, which creates jobs for disadvantaged groups and produces goods and services, thus addressing a wide variety of issues important to society. Based on recent research by the European Commission, the definitions of social enterprises that are most commonly used in the EU member states can be divided into:

- organisational definitions, focusing on the intrinsic characteristics of social enterprises and using specific features common to all eligible entities;

- sectoral definitions, covering only certain types of organisations working in the field of social inclusion, mainly by facilitating the integration of those excluded from the labour market; such definitions are usually policy-based and linked to funding programmes (mainly those resulting from the implementation of the European Social Fund) and policies aimed at promoting social inclusion (European Commission, 2020a).

The sector definition is a sub-component of the organisational definition, narrowing down the field of activity and the type of social impact. A social enterprise's potential stems from its specific characteristics, hence the definition of a social enterprise is far 
from 'neutral' and has important policy implications (e.g. access to finance). It is worth underlining that definitions in EU legislation are adopted to implement specific incentives and not to propose a definition to be used by member states in their legislation.

\section{Knowledge of social entrepreneurship in Poland, Italy and North Macedonia}

Due to the lack of a consistent definition of a social enterprise, it is often misunderstood by the general public; there are also significant differences between countries. It is confirmed by research conducted among the so-called stakeholders (those associated with the social entrepreneurship sector) and young people from Italy, Poland and North Macedonia ${ }^{2}$.

The research sample was selected intentionally. The respondents were young people aged 18 to 35, youth workers and other stakeholders from Poland, Italy and North Macedonia. In total, 420 young people and 35 stakeholders completed the questionnaires. The young people involved in the study were mainly under $25(68.2 \%)$, living in rural areas or small towns (60.2\%) and female (64.2\%). Most of them were students (48\%), followed by those employed in enterprises (19\%), interns/volunteers (12\%), those employed in public administration (5\%), in non-governmental organisations (4\%), entrepreneurs (4\%), as well as the unemployed (12\%). Stakeholders involved in the study were mainly aged 36-50 (67.4\%), living in large cities (over 500000 inhabitants - 34.8\%; from 100000 -500000 inhabitants $-30.4 \%)$, male (56.5\%). They came from different backgrounds and had differing professional status (entrepreneurs, social entrepreneurs, those employed in non-governmental organisations, those employed in public administration - related to supporting social entrepreneurship, those employed in enterprises). However, all of them were related to the social economy sector and/or were working with young people. Online surveys were prepared separately for young people and stakeholders. The surveys were distributed over the internet and collected in June and July 2020.

Stakeholders were asked about their understanding of social entrepreneurship and to identify three main features of a social enterprise - typical features that distinguish it from traditional business (open-ended question). The responses varied widely. Most of the respondents indicated achieving social goals (12 responses), reinvesting profits (12), social impact (10), solving social problems (10), and acting and responding to the needs of the local community (10 responses). Stakeholders indicated many other features (e.g. employing people at risk of social exclusion, reinvesting profits, innovative approaches, mission, joint action, participatory management, solidarity, inclusiveness), but these responses appeared much less frequently. Thus, there is no one clear association, one feature that would be considered the most important by all for a social enterprise. Interestingly, Polish respondents indicated the social goal of the activity more often, Italians - the social impact, while the respondents from North Macedonia most often referred to solving social problems.

In the same survey, respondents (both stakeholders and young people) were asked to indicate what type of enterprise/organisation they consider to be a social enterprise.

\footnotetext{
${ }^{2}$ These studies also included Jordan, but due to the specificity of this country and difficulties in accessing other data, including statistical ones, Jordan is not the subject of this article. The full research report is available at https://innose.up.krakow.pl/results/.
} 
The following options were available (multiple choice):

- businesses solving social problems (e.g. combating poverty and social exclusion),

- an enterprise that employs people with fewer opportunities (e.g. disability, educational difficulties, cultural differences, health problems, economic, social and geographical obstacles),

- an enterprise allocating profits for social purposes,

- non-profit organisations,

- an enterprise financed by subsidies,

- an enterprise that donates part of its profit to charity,

- businesses whose primary purpose is to exert social influence while remaining profitable.

The distribution of responses selected by stakeholders and young people from these three surveyed countries is presented in Figures 2 and 3.

Stakeholders most often indicated: (a) businesses solving social problems ( $89 \%$ of all respondents), (g) businesses whose primary goal is to generate some social impact while maintaining profitability (74\%), (b) an enterprise employing people with fewer opportunities (66\%). Surprisingly many people indicated answer (d) 'non-profit organisation'. It may indicate that many people equate social enterprises with the non-profit sector (this answer was chosen particularly often by Polish respondents).

Figure 2. Stakeholders - which of the following do you consider a social enterprise? (multiple answers possible; a percentage of respondents who indicated a given option)

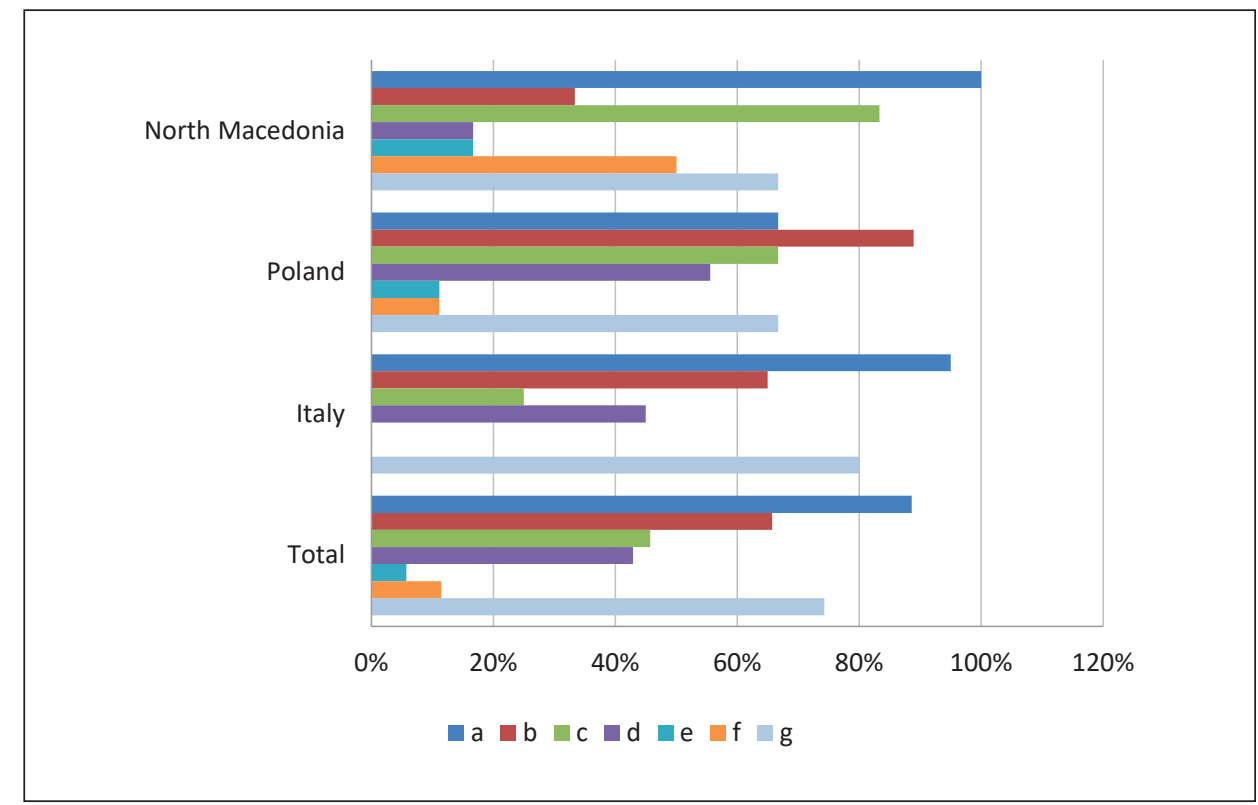

Key: a. business solving social problems; b. enterprise that employs people with fewer opportunities; c. enterprise allocating profits for social purposes; $d$. non-profit organisation; e. subsidised enterprise; f. enterprise that donates part of its profits to charity; g. business whose primary goal is to make social impact while remaining profitable

Source: author 
Figure 3. Young people - which of the following do you consider a social enterprise? (multiple answers possible; a percentage of respondents who indicated a given option)

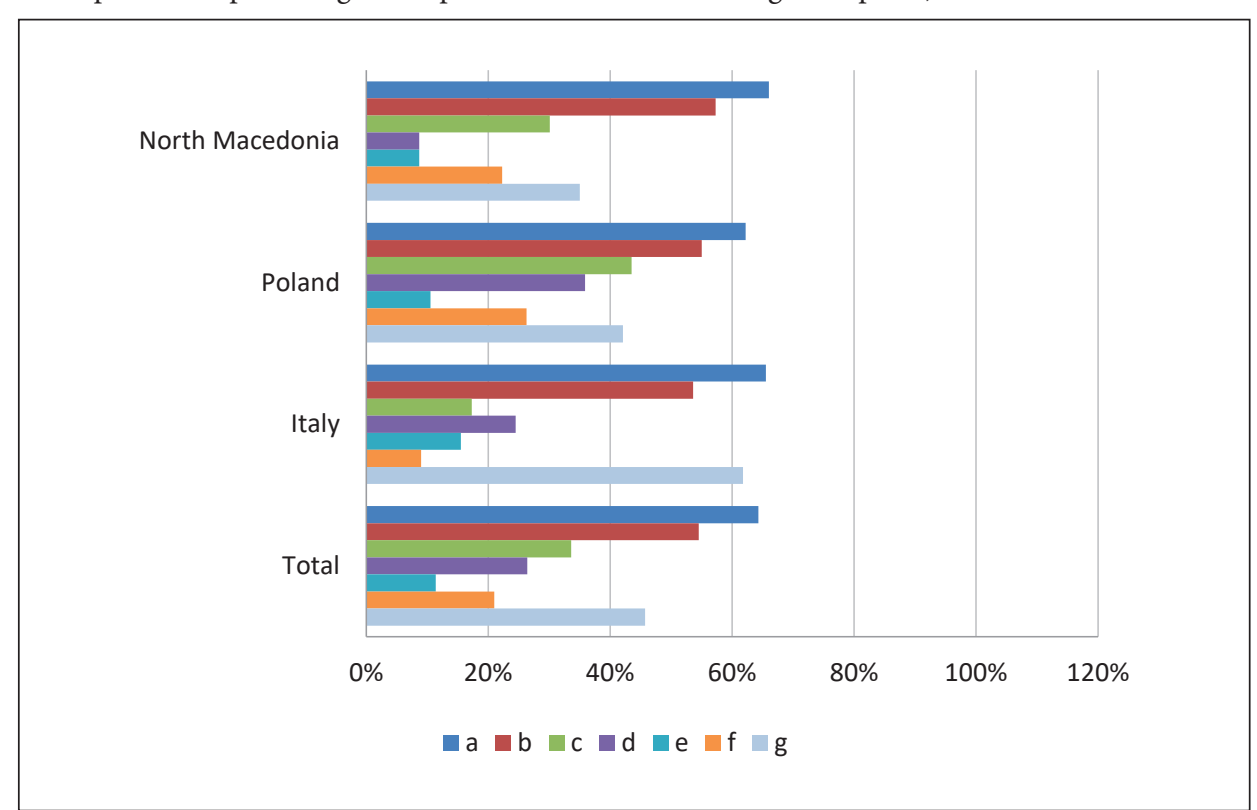

Key: a. business solving social problems; b. enterprise that employs people with fewer opportunities; c. enterprise allocating profits for social purposes; $d$. non-profit organisation; e. subsidised enterprise; f. enterprise that donates part of its profits to charity; g. business whose primary goal is to make social impact while remaining profitable.

Source: author

The responses to the same question among young people were slightly different. Young people perceive social enterprises mainly as businesses solving social problems, but the percentage of respondents who chose this answer was as much as 25 percentage points lower than among stakeholders. The biggest difference in relation to the stakeholders can be seen in (g) 'businesses whose main goal is to generate social impact while maintaining profitability' - young respondents indicated this answer much less often (46\%). The social impact generated by social enterprises is much less noticeable among young people. Interestingly, this was not the case for Italy where this option was chosen most often. Another difference is that an enterprise that donates part of its profit to charity and a subsidy-funded enterprise were treated as social enterprises - young people were more likely to point to this option. It can be concluded that their understanding of social entrepreneurship is intuitive, not supported by actual knowledge

\section{Social entrepreneurship ecosystems in Italy, Poland and North Macedonia}

Social entrepreneurship and the social economy are unevenly developed around the world. This is due to many factors ranging from the general level of socio-economic development in individual countries to a specific development stage in the concept of social economy itself in given countries. There are those where social entrepreneurship is 
a fairly young concept that has appeared in public debate only in recent years (e.g. North Macedonia). There are also countries such as Italy where social entrepreneurship is a concept that has been around for a long time, but is regulated in various ways. Finally, Poland is somewhere in the middle and clearly differs from the countries mentioned above.

The history of social enterprises in Italy is closely linked to the characteristics and evolution of its welfare system. It covers nearly 40 years and shows diverse trends in the different organisation types that make up the spectrum of social enterprises. The concept of 'social enterprise' was introduced in Italy earlier than elsewhere - in the late 1970s - to denote the first 'social solidarity cooperatives' which arose on the voluntary initiative of groups of citizens to undertake economic activities as part of a social project (Borzaga, Fazzi, Galera, 2016). After more than ten years of unregulated development, this new cooperative was recognised in 1991 under Law 381/1991 on 'social cooperatives'. This law not only recognised a new form of cooperative that had developed since the 1970s but introduced a new type of enterprise with a clear social purpose. Act 381 regulates two social cooperatives: Type A provides social, health and educational services; Type B involves people with special needs. The gradual recognition of voluntary organisations and social cooperatives, and the growth and diversification of needs that arise in a society increasingly attract public money. As a result, the number of such initiatives has increased dramatically over the years, stimulating a collective debate on the most appropriate organisational solution to guarantee an adequate supply of social services and harness the contribution of civil society.

Polish social enterprises have their roots in voluntary involvement and cooperative movements long before the Second World War. These traditions survived despite the communist regime and then revived after the democratic breakthrough of 1989, enabling the development of associations and foundations in the following years (Giza-Poleszczuk, Hausner, 2008). The concept of social entrepreneurship appeared in public discourse in Poland in connection with accession to the EU and its related policies. Poland's accession and access to funds from the organisation's budget played a key role in stimulating the development of social enterprises (Murzyn, 2018). This has led to two parallel processes: the evolution of traditional legal forms, such as foundations and associations, towards market orientation and the legal recognition of new types such as social cooperatives.

On the one hand, Poland is characterised by an increase in the number of social enterprises but, on the other, by their relatively poor development. A study conducted by Eurofund questioned the sustainability of social enterprises (Eurofund, 2019: 21). The respondents indicated that many operate only as long as they receive financial support for their activity (including remuneration). The development of social enterprises is also prone to a kind of 'stigmatisation', i.e. perceiving them only through the prism of difficulties experienced by their employees, and not the quality of their offer. This makes integration with the mainstream economy difficult.

The history of social enterprise practice in North Macedonia is, in turn, closely related to socialist self-government cultivated during the Yugoslav era and the emergence of various forms of economic cooperation, promoting solidarity and mutual aid (Sivcev, Randelovic, 1966). The initiatives identified during the socialist era can be seen as a positive legacy (Klekovski et al., 2011) that paved the way for the emergence of today's social enterprises. In North Macedonia, social enterprise and social entrepreneurship appeared in third sector discourse in 2009-2010, but there is conceptual confusion when discussed 
in public. There is no accepted definition of a social enterprise between stakeholders and the government. The general understanding of the concept among policymakers, the donor community, civil society and social enterprises is limited to work-integrated enterprises (aimed at integrating people in more complex life situations and at risk of social exclusion). The ongoing process of EU integration has played a crucial role in boosting social enterprises' development in North Macedonia. This process has resulted in two key reforms that fostered social enterprises' emergence, namely in the market-oriented associations' sector and in the welfare system, adopting a decentralised approach (European Commission, 2018).

These diverse experiences of individual countries are reflected in the number and degree of social enterprises' acceptance (Table 1).

Table. 1. Estimated number and acceptance level of social enterprises (SE) in Italy, Poland and North Macedonia

\begin{tabular}{|l|c|c|c|c|c|c|}
\hline \multicolumn{1}{|c|}{ State } & Year & $\begin{array}{c}\text { Estimated } \\
\text { number } \\
\text { of SE }\end{array}$ & $\begin{array}{c}\text { Number } \\
\text { of SE } \\
\text { per million } \\
\text { population }\end{array}$ & $\begin{array}{c}\text { Estimated } \\
\text { number } \\
\text { of employees }\end{array}$ & $\begin{array}{c}\text { The degree } \\
\text { of data } \\
\text { reliability }\end{array}$ & $\begin{array}{c}\text { Applying } \\
\text { and } \\
\text { accepting } \\
\text { the SE } \\
\text { concept }\end{array}$ \\
\hline Italy & 2017 & 102461 & 1694 & 894800 & very high & very high \\
\hline Poland & $2016-2019$ & 29535 & 768 & 428700 & high & medium \\
\hline $\begin{array}{l}\text { North } \\
\text { Macedonia }\end{array}$ & $2013-2015$ & 551 & 266 & no data & low & low \\
\hline
\end{tabular}

Source: author - based on the European Commission 2020a

Considering the range of social enterprises operating in Italy, this phenomenon turns out to be numerically significant irrespective of their legal form. Based on the available data on social cooperatives, social enterprises and associations and foundations operating in the market, the estimated number in 2017 was over 102 000, representing almost 900000 paid workers and an annual turnover of EUR 42700 million (European Commission, 2020b). Italy also has the most significant cooperative sector in Europe, generating around EUR 150 billion in annual revenues (CICOPA, 2017). There are no official estimates of the number of social enterprises in Poland. Based on available data on individual types, the total number is estimated at 29 535. They employ 428700 people, but their employment potential measured as full-time jobs is lower (European Commission, 2020c). Estimating the number of social enterprises in North Macedonia is even more difficult due to the multiplicity of legal forms (associations, sheltered workshops, cooperatives) under which such enterprises try to operate, and the lack of specific data on which of these entities fully correspond to the definition of a social enterprise. According to estimated data collected for the European Commission, about 550 entities can be included in this category, while there is no data on employment level (European Commission, 2018).

The environment is vital for developing social entrepreneurship, confirmed by the research and analyses conducted so far (Kerlin, 2017; Roy et al., 2015). The institutional environment is of particular importance, i.e. "various social, cultural and political norms (institutions) that determine the way social actors operate" (North, 2017: 6). At the same time, the concept of the entrepreneurial ecosystem has emerged, which is considered to 
Figure 4. Key elements, outputs and outcomes of the entrepreneurial ecosystem

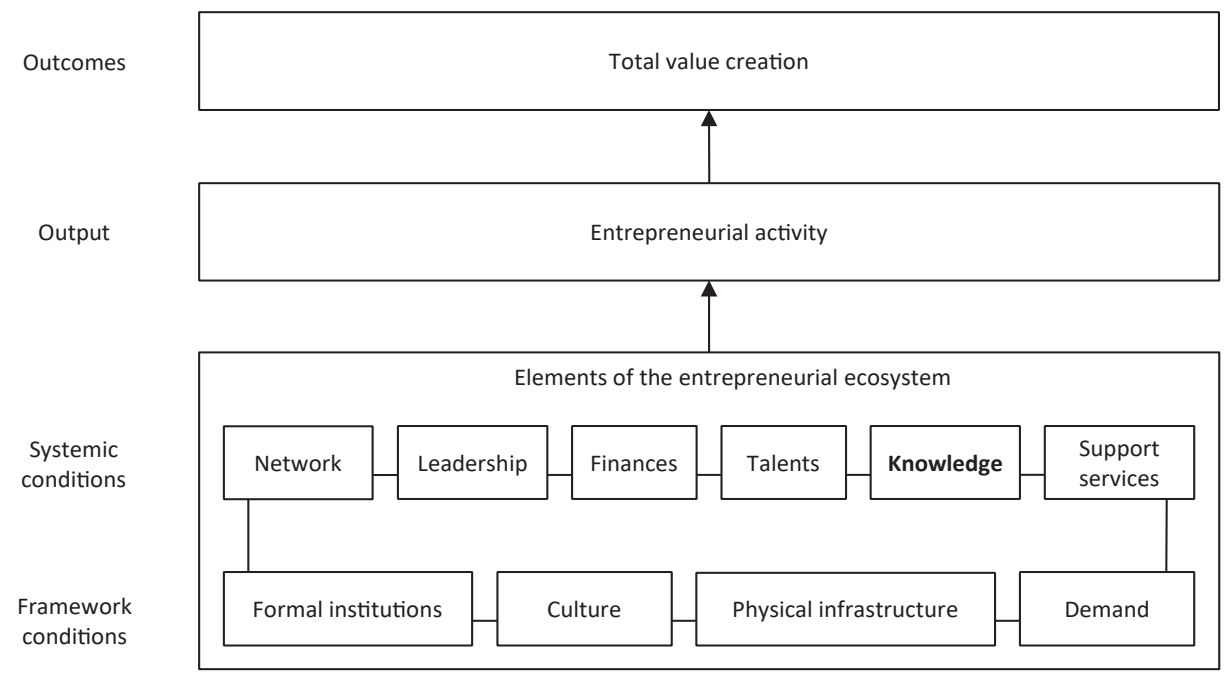

Source: Stam (2015: 1765)

be a set of interdependent actors and factors managed in such a way as to enable productive entrepreneurship in a given territory (Stam, 2015). The entrepreneurial ecosystem elements that can be distinguished are 'framework' and 'system conditions' (Figure 4). Framework conditions include social conditions (informal and formal institutions) and physical conditions that enable or restrict interpersonal interactions.

Moreover, access to a more or less exogenous demand for new goods and services is also of great importance. System conditions are at the heart of the ecosystem and include entrepreneurial networks, leadership, finance, talent, knowledge and support services. The presence of these elements and the interaction between them largely determine the success of an ecosystem.

The entrepreneurial activity that results from the entrepreneurial ecosystem is increasingly seen as an essential driver of economic growth and development. There is evidence that the relationship between entrepreneurship and growth varies systematically between groups of regions, and these differences are related to regional characteristics that can be linked to the quality of a region's entrepreneurial ecosystem (Content et al., 2020). For example, there is evidence that better local institutions help small and medium-sized enterprises increase their productivity. Besides, the influence of institutions interacts with specific company characteristics such as size, age, human capital and productivity levels, as well as the sector in which it operates (Agostino et al., 2020).

The social enterprise ecosystem in Italy is shaped by the interplay between key actors who have contributed to the recognition of the specificity of social enterprises, developed support policies and measures to support their replication and scaling, and have played a role in making social enterprise visible (European Commission, 2020b). Key actors are national and local policymakers, research and education providers, social enterprise networks and financial intermediaries. 
Several key actors are part of the social enterprise ecosystem in Poland. They operate at all administrative levels, i.e. national (Ministry for Social Policy), regional and local (Social Economy Support Centres, or Ośrodki Wsparcia Ekonomii Społecznej - OWES) to create policy programmes for social enterprises and support their legal, financial and know-how development. OWES is intended to provide a wide range of support to existing social enterprises as well as organisations or groups of people interested in starting one. Polish social enterprises are entitled to benefit from support aimed at the organisation of the social economy. In particular, it is organised as part of the National Program for the Development of the Social Economy, which is the basic document defining the direction of development of the social economy and social enterprises in Poland

By contrast, in North Macedonia, public policy efforts until recently have been primarily geared towards overcoming the weaknesses and internal barriers of social enterprises, rather than developing a supporting ecosystem. A continuing challenge is the lack of cooperation between the stakeholders who are part of this ecosystem. There is no clear division of power, and no specific responsibilities and connections between government, investors, the business sector and educational institutions.

In 2016, the Thomson Reuters Foundation (2020), in cooperation with Deutsche Bank, published a ranking, based on research among experts from 45 countries, which assessed the environment for social entrepreneurs' activities. Six key areas were taken into account: public support, the attraction of qualified staff, social understanding, the opportunity to earn a living, development and gaining momentum, access to investment. This study was repeated in 2019 and according to its results, the best conditions for development were in Canada, Australia and France, in that order. Italy took 18th place, while Poland was 35th. Both countries had worsened their position compared to 2016 (then Italy was 12 th, Poland -18 th). North Macedonia was not included in this survey.

\section{Conclusions}

The importance of and interest in social entrepreneurship has increased in recent years and is becoming an important factor in regional and local development. However, public knowledge of social enterprise ideas, social entrepreneurship and the social economy is still limited. The results of this research confirm it. Young people understand social entrepreneurship quite intuitively. In turn, even the stakeholders themselves, i.e. people related to social entrepreneurship, define a social enterprise differently. There are also visible differences in this respect between countries. Additionally, the variety of legal forms in which social enterprises operate creates confusion regarding the understanding of the concept itself.

Knowledge is an essential element of the entrepreneurial ecosystem and is one of the key areas considered by the Thomson Reuters Foundation in the research on the surroundings of social enterprises' activities. Therefore, for social entrepreneurship to develop, it is necessary to raise awareness of this phenomenon. It is crucial in the case of young people who have to choose their career path. If they are to make informed choices, it is essential to integrate social entrepreneurship into mainstream entrepreneurship education.

There are considerable differences between countries in terms of origin, historical and cultural traditions, the size and diffusion of social enterprises, the activities carried out, and the legal and policy arrangements to improve the environment in which they operate. 
These various social entrepreneurship ecosystems are also closely related to the level of socio-economic development in individual countries. It is seen in the three countries analysed in this article. How the research sample was selected, and its size means that the research conclusions are not representative. Nevertheless, they allow attention to be drawn to a significant problem: the deficiencies in knowledge about social entrepreneurship and the ambiguity of this phenomenon's definitions.

\section{References}

Agostino, M., Tommaso Di, M.R., Nifo, A., Rubini, L., Trivieri, F. (2020). Institutional quality and firms' productivity in European regions. Regional Studies, 54(9), 1275-1288. doi: $10.1080 / 00343404.2020 .1712689$

Bornstein, D. (2004). How to change the world: Social entrepreneurs and the power of new ideas. New York: Oxford University Press.

Borzaga, C., Fazzi, L., Galera, G. (2016). Social enterprise as a bottom-up dynamic: part 1. The reaction of civil society to unmet social needs in Italy, Sweden and Japan. International Review of Sociology, 26(1), 1-18. doi: 10.1080/03906701.2016.1148332

CICOPA. (2017). Cooperatives and employment: Second global report. Brussels: CICOPA.

Content, J., Bosma, N., Jordaan, J., Sanders, M. (2020). Entrepreneurial ecosystems, entrepreneurial activity and economic growth: new evidence from European regions. Regional Studies, 54(8), 10071019. doi: $10.1080 / 00343404.2019 .1680827$

Dees, J.G. (2001). The meanings of 'social entrepreneurship'. Working paper. Stanford University.

Defourny, J., Nyssens, M. (2008). Social Enterprise in Europe: recent trends and developments. EMES Working Paper, 08/01.

Eurofound. (2019). Cooperatives and social enterprises: Work and employment in selected countries. Luxembourg: Publications Office of the European Union.

European Commission. (2020a). Social enterprises and their ecosystems in Europe. Comparative synthesis report. (Authors: C. Borzaga, G. Galera, B. Franchini, S. Chiomento, R. Nogales, C. Carini). Luxembourg: Publications Office of the European Union.

European Commission. (2020b). Social Enterprises and their ecosystems in Europe. Country Report: Italy. (Author: C. Borzaga). Luxembourg: Publications Office of the European Union.

European Commission. (2020c). Social enterprises and their ecosystems in Europe. Updated country report: Poland. (Author: A. Ciepielewska-Kowalik). Luxembourg: Publications Office of the European Union.

European Commission. (2018). Social enterprises and their ecosystems in Europe. Country fiche: Former Yugoslav Republic of Macedonia. (Authors: K. Ilijevski, A. Iloska). Luxembourg: Publications Office of the European Union.

Giza-Poleszczuk, A., Hausner, J. (2008). Wprowadzenie - ekonomia społeczna i rozwój. In: A. GizaPoleszczuk, J. Hausner (ed.), Ekonomia społeczna w Polsce: osiagnięcia, bariery rozwoju i potencjat wświetle wyników badań. Warszawa: Fundacja Inicjatyw Społeczno-Ekonomicznych, 11-40.

Hausner, J., Laurisz, N. (2008). Czynniki krytyczne tworzenia przedsiębiorstw społecznych. Przedsiębiorstwo społeczne. Konceptualizacja. In: J. Hausner (ed.), Przedsiębiorstwa społeczne $w$ Polsce. Teoria i praktyka. Kraków: Uniwersytet Ekonomiczny w Krakowie, 9-31.

Kerlin, J.A. (2017). Shaping social enterprise: Understanding institutional context and influence. Bingley: Emerald Publishing Limited.

Klekovski, S., Stojanova, D., Jakovlevska, G., Nuredinoska, E. (2011). Civic engagement - long road to go. Skopje: Macedonia Center for International Cooperation.

Krajowy Program Rozwoju Ekonomii Społecznej do 2023 roku. Ekonomia Solidarności Społecznej. (2019). Annex to Resolution No. 11 of the Council of Ministers of January 31, 2019 (item 214). 
Murzyn, D. (2018). Ekonomia społeczna jako przykład działań na rzecz rozwoju inkluzywnego. In: D. Murzyn, J. Pach (eds.), Ekonomia społeczna - między rynkiem, państwem a obywatelem. Warszawa: Difin, 348-367.

North, D.C. (2017). Institutions, Institutional Change and Economic Performance. New York: Cambridge University Press.

Roy, M.J., McHugh, N., Huckfield, L., Kay, A., Donaldson, C. (2015). The most supportive environment in the world? Tracing the development of an institutional 'ecosystem' for social enterprise. Voluntas, 26(3), 777-800.

Seelos, C., Mair, J. (2005). Social entrepreneurship: Creating new business models to serve the poor. Business Horizons, 48(3), 241-246.

Sivcev, B., Randelovic, V. (1966). The cooperative movement in Yugoslavia. Belgrade.

Stam, E. (2015). Entrepreneurial Ecosystems and Regional Policy: A Sympathetic Critique. European Planning Studies, 23(9), 1759-1769. doi: 10.1080/09654313.2015.1061484

Thomson Reuters Foundation. (2019; 2020, October 17). The best countries to be a social entrepreneur 2019. Retrieved from: https://poll2019.trust.org/

Dorota Murzyn, PhD, Pedagogical University of Krakow, Institute of Law and Economics, Department of Entrepreneurship and Social Innovation. Economist and political scientist. Her expertise mainly covers the issue of EU cohesion policy and its impact on Poland's socio-economic development, and her research interests focus on: European integration, economic policy, regional development, social innovation, social economy and social entrepreneurship.

ORCID: https://orcid.org/0000-0003-2032-8401

\section{Address:}

Uniwersytet Pedagogiczny im. Komisji Edukacji Narodowej w Krakowie

Instytut Prawa i Ekonomii

Katedra Przedsiębiorczości i Innowacji Społecznych

ul. Podchorążych $2 / 224$

30-084 Kraków, Polska

e-mail: dorota.murzyn@up.krakow.pl

Project "INN@SE - Innovative social entrepreneurship with youth engagement" is financed by the European Union as part of the Erasmus+ Programme, KA2, Strategic Partnerships, Cooperation for innovation. 